\title{
The more things change...
}

\section{The past as a signpost for the future}

was pleased when ACRL President Fran-

ces Maloy asked me to write a column for her on libraries and change, but somewhat less pleased when she went on to say that I had been around for such a long time that I could provide an historical perspective.

So I will admit it-I have been a librarian for 30 years and an academic librarian for 25 of them. In those 25 years, I have always had OCLC, performed online searching, and offered "bibliographic instruction"; and for over 20 years, I have owned a personal computer and used e-mail.

Maloy has noted that: "We know that technology has been the major driver for change in libraries for over 30 years and has accelerated in recent years." ${ }^{1}$ Paula Warnken, Associate Provost for Information Resources at the State University of New York-Cortland, documented changes over the past 15 years from an academic perspective. ${ }^{2}$ This article is a look back over the past 30 years from a very personal perspective.

\section{Challenges past and present}

Some of the challenges 30 years ago were the same as the challenges today:

- the need to identify appropriate technology and not just do it because it can be done

- the need to match the existing technologies to the needs and skills of our users and to the mission of our parent organizations; and

- the need to raise the level of awareness of what we have to offer.

Two things have changed in that time. The first is a series of changes in the educational environment, such as the pace of change, the learning and teaching styles of our two primary user groups - students and faculty - and the very nature of the university from the bastion of the ivory tower to an extension of a board room. Fundraising and rankings are two driving forces in top institutions; students and faculty are bought; state budgets are decreasing, and endowments are flat. The cost of education keeps going up faster than family incomes, ${ }^{3}$ and technology and the costs associated with it become more pervasive. In addition to rising costs of both public and private college education, we are also entering a period of declining numbers of college-age students, with the number of students aged 15-19 peaking in 2008 and then falling back to 2004-2005 levels in ten years. ${ }^{4}$

The second thing that has changed is our perception of ourselves. We at least articulate new roles as teachers and trainers, partners and consultants, resource managers and marketing managers. We recognize that just storing the books is no longer a sustainable position, both in terms of roles and perceptions and in terms of the realities of physical space.

Many things have also stayed the same. Thirty years ago, in my very first library job at my local public library, we were debating the costs and benefits-amazing that we actually did that - of bringing in OCLC. The selling point was supposed to be that, in the end, we would save money by requiring fewer people to do the work. Maybe in

Ruth A. Pagell is executive director of the Goizueta Business Library at Emory University, e-mail: Ruth_ Pagell@bus.emory.edu

(c) 2005 Ruth A. Pagell 
manufacturing, technology solutions save money, but that was not the case then and it is not the case now for libraries. In fact, a recent Association of American Universities provost report complains that we have not seen the cost savings from technologies in libraries. ${ }^{5}$ This might be in part because we have not changed our organizational structures adequately to meet the environmental and technological changes. What the provosts are not seeing is that this is also the result of increases in programs and services that the technology has enabled.

\section{Regaining sight of our purpose}

Maloy makes the case for libraries playing an important role in education, and sorry is the state that we have to be reminded that this is a goal. But in the 1980s and 1990s, we became more enamored by the technology and lost sight of the purpose. Of course, the era of technology experimentation was better than the era in which I entered academic libraries. That was the era of the library as the book repository, though that is lurking ever closer to the surface as we grapple with the print versus electronic conundrum along with on- or offsite storage.

I get tired of hearing how new and different everything is. Let's put our work in perspective: we have always been driven by technology, from the invention of the printing press (which changed the nature of what we collected) to the invention of the typewriter (which improved the way we could provide access to what we collected). As we moved from manual production of cards to the electronic card catalog to the integrated library system, what I have seen is a focus on how these technological changes can make our jobs easier for us; therefore, our electronic card catalogs have looked very much like our file drawers.

What I am seeing today is a growing awareness that we are not in the business of making our jobs easier but in the business of improving access for our users. While the terms customer-focused, user-centric, or customer delight might feel trite and un- comfortable, we are at long last responding to our users' needs. That, of course, is not enough. It was a perception of responding to user needs that led us through those gloomy years of just collecting and storing materials, hiding behind a desk for fixed hours, slowly dabbling with CD-ROMs, and creating print pathfinders that we displayed in our libraries for our patrons to come in and find.

I have been fortunate through my years of library work to have worked in places where tradition was not the norm. In my first academic job 25 years ago, we were offering table-of-contents and document-delivery services to faculty, something many libraries are still not offering. During the mid-1980s at the Lippincott Library of the Wharton School, we worked closely with our partners in the information industry to try out new products and then share what we had learned by writing articles in publications such as Online and Database, more popular with special than academic librarians., 6 We introduced do-ityourself end-user searching over 20 years ago, analyzed the confusion over full-text articles and full-text journals, and evaluated the strengths and weaknesses of cross-database searching, which today goes under the more jargony name of "federated searching" but remains as primitive.

What we learned then is what we are seeing in academia today: end-user searching is a huge success; trying to sort out the whole full-text coverage question was complicated then and more complicated now; and the challenges of doing any kind of sophisticated retrieval across files with different structure and different content, from images of articles to company directories to statistical tables, does everyone a disservice. What we have learned is that we do not have to be afraid of end users doing their own research, as long as those end users are not searching Google.

\section{Evolving roles}

Back in the day, as they now say, the librarian always sat at her desk and pointed a user to the appropriate print index; the user determined which articles she or he wanted 
and went off to find them. Then we became intermediaries. Only highly trained librarians in select academic libraries searched sophisticated and expensive databases such as "Dialog" so the users' access to a growing body of electronic information was dependent on the librarian's skill level and the user's budget. In many ways, we have put the user back in control of his or her information selection and retrieval by providing access not only to indexes but to articles not only on the library shelves but anywhere in the world our authorized users happen to be.

It has also become more complicated, with more choices and with the embargoes and journal wars, and publishers and database aggregators fighting over who has access to what for what dates. We have stepped in and seen that we have a crucial role in training users either in groups or through individual consultations on how to use the resources. Our roles are changing from deference to faculty to partnering with faculty. Faculty certainly know their disciplines better than most of us but they cannot possibly keep up with all the changes in information technology as it applies to scholarly communication and teaching.

I taught a business librarianship class for many years and focused on teaching students the basics of business theory and the many tools of information retrieval. A colleague who has not taught this course at his institution in many years asked what I would teach now, so I thought about what it is we-not only in business but certainly in general at Emory-are looking for from new librarians. To get an interview with our business library, you have to show knowledge of your subject, either through an undergraduate or graduate business degree, experience in another academic- or research-based special library, or real-world experience in business, and show an understanding of the difference between research (which we view as consultation) and reference (which translates into "where's the book?").

Subject expertise is becoming the norm throughout Emory libraries. Candidates also have to show that they have been innovative, creative, or proactive in their approach to service. These qualities will get a person in the door. But to be successful, at least in our environment today, the potential employee also has to be able to teach, present, or instruct-whichever verb you prefer. This goes well beyond the skills that are taught in library school or were required of us.

For the 21st century academic librarian, two things are givens: the first is that our programs and services are dependent upon technology; and the second is that there will always be change at an ever-increasing pace. How the changes play out in our institutions should vary, based on the needs of our own users and the goals of our parent institutions and on our abilities to control and positively integrate the changes into our programs and services.

The key is to embrace change as opportunity.

\section{Notes:}

1. Frances Maloy. "Creativity as Leadership Strategy in Times of Change," College E Research Library News 65, 8 (September 2004) 444.

2. Paula Warnken, "New Technologies and Constant Change: Managing the Process," Journal of Academic Librarianship 30, 4 (July 2004) 322-327.

3. College Board. Trends in College Pricing 2004, www.collegeboard. com/prod_downloads/press/cost04/ 041264TrendsPricing2004_FINAL.pdf.

4. Global Market Information Database, Euromonitor, searched November 2004.

5. American Association of Universities Provost Session, OCLC Environmental Scan: Pattern Recognition, September 12, 2004 , Newport Beach, CA, e-mail notes, November 9, 2004.

6. Michael Halperin and Ruth A. Pagell. "Free 'Do-it-Yourself' Online Searching ... What to Expect," Online 9, 2 (March 1985) $82-4$.

7. Ruth Pagell. "Searching IAC's Full-Text Files: It's Awfully Confusing," Database 10, no.5 (October 1987) 39-46. z 